\title{
The Influence of Self Efficacy and Adversity Quotient: How is The Vocational Student Entrepreneurial Intention?
}

\author{
Wahyu Kurniawati ${ }^{1}$, Novi Marlena ${ }^{2}$ \\ Faculty of Economics, Surabaya State University \\ Email: wahyukurniawati@mhs.unesa.ac.id
}

\begin{abstract}
The aims of this study is to determine the effect of self efficacy and adversity quotient on entrepreneurial intentions of students of SMK Negeri 1 Kanor Bojonegoro. This study uses descriptive research and quantitative approach. The Respondent in this study is 56 students of Grade XI of State Vocational School 1 Kanor from Marketing Department. Saturated sampling is a technique used for sampling in this study. Questionnaires and structured interviews used in data retrieval techniques. Data analysis techniques in this study used multiple linear regression equations. In this study provide conclusions: 1) there is an effect of self efficacy on entrepreneurial intentions in Grade XI SMK Negeri 1 Kanor, Department of Marketing, 2) there is an influence of adversity quotient on entrepreneurial intention in Grade XI students of State Vocational School 1 Kanor Department of Marketing, 3) there are selfinfluences simultaneous efficacy and adversity quotient on entrepreneurial intentions in Grade XI SMK Negeri 1 Kanor, Department of Marketing. The ability of self efficacy and adversity quotient variables explains the effect on entrepreneurial intentions by 48 percent.
\end{abstract}

Keywords: Self efficacy, Adversity quotient, Entrepreneurial intention

\section{INTRODUCTION}

Self efficacy is related to student's self-confidence of their ability to achieve the desire for entrepreneurship. The formation of self efficacy for students is teached through entrepreneurial learning on opportunities material and business risks that teach students to have an attitude of confidence. Selfconfidence that oneself is capable of doing a good behavior (Setiawan, 2014). Self-efficacy already exists within students who will be more trained through entrepreneurial learning on business opportunity and risk methods so that students are expected to be able to learn from experiences to become responsible, more confident, creative, dare to take risks, try hard, discipline and confident with self abilities if want to set up a business. Self-efficacy and family environment have a positive and significant effect on the interest in entrepreneurship of students of SMK Negeri 1 Turen (Evaliana, 2015). Individuals with high self efficacy will be able to: 1) face the task diligently and with great desire, 2) tend to do a certain task even though it is difficult and see that the task is not something to be avoided, 3) lack of knowledge, skills and hard work will result a failure. While individuals with low self efficacy 1) in the face of a difficult task do not think of a good way to solve it, 2) tend to reduce effort and give up quickly, 3) avoid many challenging and difficult tasks, 4) not diligently trying to do tasks that have given (Santrock, 2010). 
Kanor Vocational High School 1 is one of the business-based Vocational Schools in Bojonegoro which has the main expertise in Business and Management. In the field of Business and Management expertise of Marketing Department, students have begun to be given about entrepreneurship theory since in the first year of Vocational High School. Providing of entrepreneurial theory at SMK Negeri 1 Kanor is to prepare graduates to be ready to work, gain experience in the proper field, instill entrepreneurial spirit to the students and open the new opportunities for entrepreneurship. So that in entrepreneurial learning theory underlies the students mindset to have high entrepreneurial intentions so that it can motivate students to choose entrepreneurship as a career choice. Building and developing entrepreneurial spirit in schools is needed for students who have the potential for entrepreneurship. Regarding the influence of entrepreneurship education, it is need an understanding of how to develop and encourage the newest of potential young entrepreneurs while they are in school (Lechner et al., 2018).

Based on the interview with Mr. Maskun as Deputy Principal Curriculum at SMK Negeri 1 Kanor stated that entrepreneurship learning through entrepreneurial theories and entrepreneurial practices can be used as a forum for students to strengthen student's abilities, encourage students' self-confidence in entrepreneurship, develop student's creativity in developing business and applying unyielding attitude for difficult situations in entrepreneurship. The implementation of entrepreneurship will indirectly provide experience and knowledge in creating new businesses or entrepreneurship. Capitalized with experience after conducting entrepreneurial activities students can have the intention of being an entrepreneur that students can create new jobs and reduce unemployment. Based on the results of interviews conducted by researchers with several students of SMK Negeri 1 Kanor, there are several students who have confidence in their abilities to set up their own business in the future and there are some students who are sure to become successful entrepreneurs with their ceativity and there are also students who lack of self-confidence in entrepreneurship.

Adversity qoutient relates to the intelligence of students in facing all the challenges that exist in entrepreneurship. Adversity Quotient (AQ) is a concept that can see how far a person can survive to face the difficulties and how to deal with such difficulties (Zahreni \& Malini, 2014). Adversity quotient is intelligence to change the difficulties, adversity intelligence, obstacles and challenges which become a great opportunity $(\mathrm{Ng}, 2013)$. The formation of adversity qoutient in students is done through entrepreneurial learning on material opportunities and business risks that teach students to face business challenges with their courages. In entrepreneurial learning on material opportunities and business risks, adversity qoutient aims to make students not afraid of failures, challenges, misfortunes, obstacles when they are going to set up a business. Their fear of business failures that they set up is the main cause of they do not want to become an entrepreneur that they are not ready to face the obstacles in the next process. 
Therefore, adversity quotient is needed for students in facing business challenges when experiencing difficulties and failures. By having adversity quotient on students, students are expected can solve their various problems, not afraid to fail, be able to compete when facing difficulties, have strong motivation, dare to take risks, always be optimistic about what they do when trying to set up a business.

Self-efficacy and adversity quotient in students can be formed because during entrepreneurial theory learning students have followed practices that related to entrepreneurship such as participating in maintaining UPJ and Field Work Practices, then the students can learn directly about business, learn to increase self-confidence and learn to find every possibility. Selfefficacy and adversity qoutient can also be formed through outside-class learning such as the practice of joining a bazaar, recycling waste to be resold and business services. With the aim that students can have strong beliefs and strong self-resistance to bring up the intention of entrepreneurship in students of SMK Negeri 1 Kanor. Entrepreneurial intentions in schools in students do not appear directly but can be formed by following entrepreneurial practices and participating in various entrepreneurship activities that presented by school or outside school. Someone who has the desire or intention to carry out an entrepreneurial action is an entrepreneurial intention (Wijaya, 2007). The benefits of entrepreneurial intentions are provide opportunities for 1) self-control, 2) making changes, 3) fully achieving self potential, 4) reaching profit, 5) active in the community, 6) do the favourite thing (Ozgul \& Kunday, 2015).

The desire for student entrepreneurship can arise if the self-efficacy and adversity quotient in the student is strong. Awareness of the strength of self-efficacy and adversity quotient in students will encourage students to have high intentions for entrepreneurship. Entrepreneurial intention is influenced by self efficacy and adversity quotient where the effect is positive the higher the self efficacy and adversity quotient in students, the higher the intention of entrepreneurship (Fradani, 2016).

The aims of this research are to determine: 1) the effect of self efficacy on entrepreneurial intentions, 2) the effect of adversity quotient on entrepreneurial intentions, 3) the effect of self efficacy and adversity quotient on entrepreneurial intentions of SMK Negeri 1 Kanor Bojonegoro students. Based on the background above, the research hypothesis are as follows: $\mathrm{H} 1=$ Self-efficacy has a positive effect on entrepreneurial intentions in SMK Negeri 1 Kanor Bojonegoro Students; H2 =Adversity quotient has a persistent effect on entrepreneurial intentions in SMK Negeri 1 Kanor Bojonegoro Students;H3 = Self efficacy and adversity quotient have a simultaneous effect on entrepreneurial intentions in Vocational High School 1 Kanor Bojonegoro Students

\section{METHOD}

This research uses descriptive research methode and quantitative approach. To see the relationship of variables to the object under study and more causal 
(causal), so that in the study there are independent and dependent variables is a quantitative approach (Sugiyono, 2017). Subjects in this study were 56 students of SMK Negeri 1 Kanor Bojonegoro from Grade XI of Marketing Department. Saturated sampling is a technique used for sampling in this study. In the technique of determining the sample, if all members of the population are used as samples, it is called saturated sampling (Sugiyono, 2017).

This research uses data collection techniques 1) questionnaire containing questions about the effect of self efficacy and adversity quotient on entrepreneurial intentions, 2) unstructured interviews used by researchers in preliminary studies to extract information from research subjects that related to self efficacy, adversity quotient and entrepreneurial intentions of SMK Negeri 1 Kanor Bojonegoro students. Data analysis techniques in this research used equations of multiple linear regressression: $\mathrm{Y}=\mathrm{a}+\mathrm{b}_{1} \mathrm{X}_{1}+\mathrm{b}_{2} \mathrm{X}_{2}$ where $\mathrm{Y}=$ entrepreneurial intention, $\mathrm{a}=$ constants of the regression equation, $b_{1}, b_{2}=$ regression coefficient value, $X_{1}=$ independent variable namely self efficacy, $\mathrm{X}_{2}=$ independent variable, that is adversity quotient.

\section{RESULTS \& DISCUSSION Results}

In this study the research respondents are 56 students of SMK Negeri 1 Kanor Bojonegoro from Grade XI of Marketing Department. The characteristics of the respondents of this study can be described as follows:

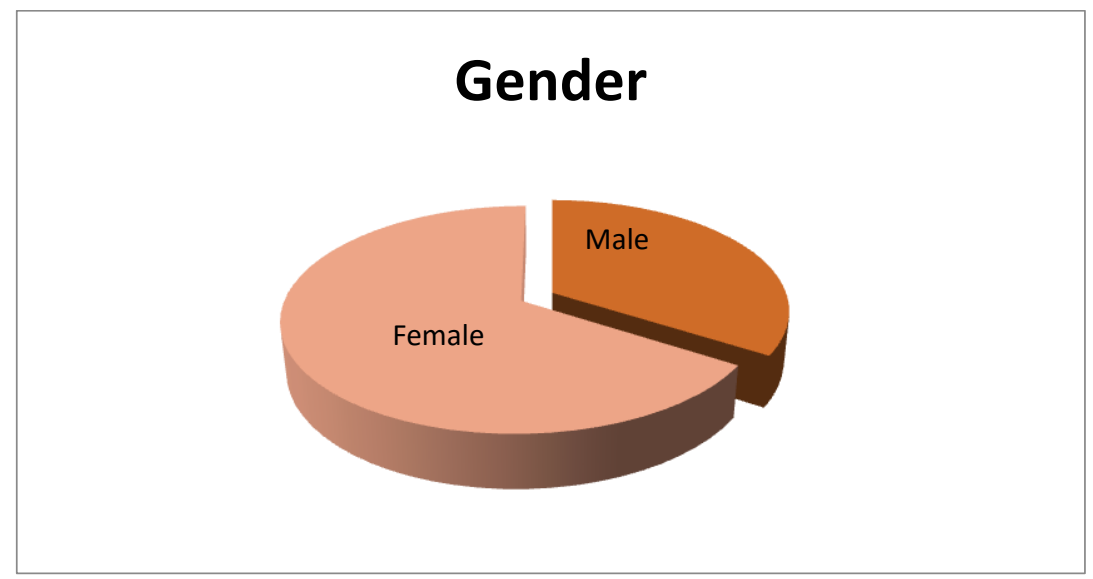

Figure 1. Characteristics of respondents of research based on gender

Based on Figure 1, the characteristics of the respondents of the study based on gender, 34 percent of respondents were male and 66 percent of respondents were female. So that it can be concluded that the majority of respondents in this study were Grade XI students of Marketing Department who had female gender. 


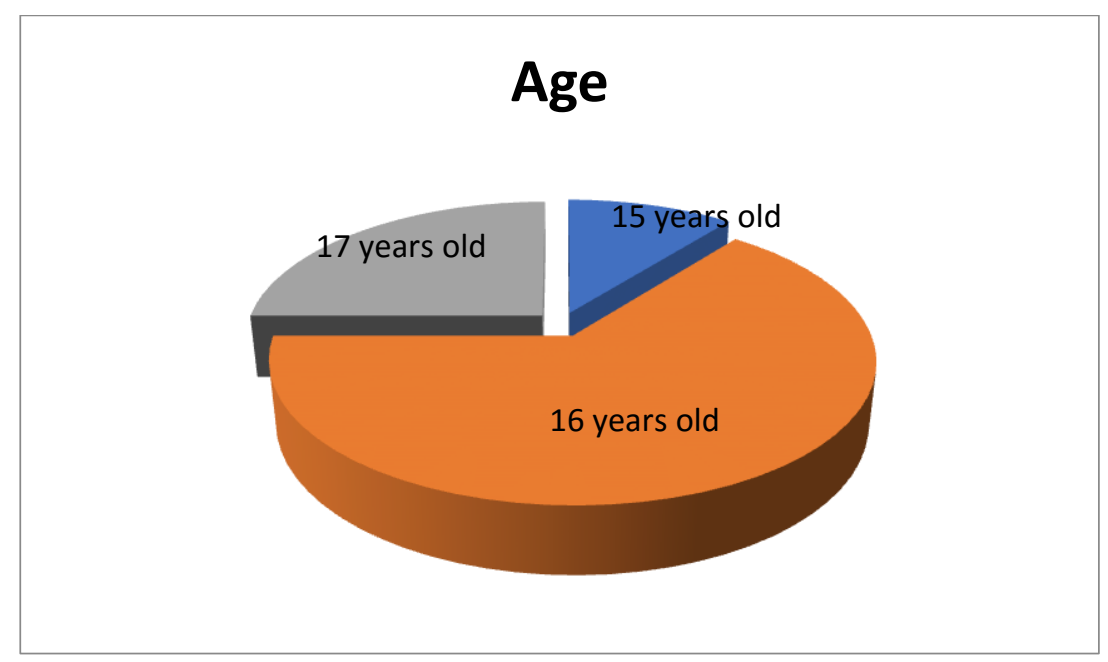

Figure 2. Characteristics of research respondents based on age

Figure 2 showed the characteristics of research respondents based on age, there were 11 percent of respondents having an age range of 15 years, 64 percent of respondents had an age range of 16 years and 25 percent of respondents had an age range of 17 years. Hence, it can be concluded that the majority of respondents in this study were students of Grade XI Marketing Department of SMK Negeri 1 Kanor Bojonegoro had a age range of 16 years. Based on the results of multiple linear regression analysis calculation, processed with the SPSS, program can be explained in the Table 1.

Table 1. Multiple Linear Regression Test Results

\begin{tabular}{|c|c|c|c|c|c|c|c|c|}
\hline \multicolumn{9}{|c|}{ Coefficients $^{\mathbf{a}}$} \\
\hline & & \multicolumn{2}{|c|}{$\begin{array}{l}\text { Unstandardized } \\
\text { Coefficients }\end{array}$} & $\begin{array}{l}\text { Standardized } \\
\text { Coefficients }\end{array}$ & \multirow[b]{2}{*}{$\mathrm{t}$} & \multirow[b]{2}{*}{ Sig. } & \multicolumn{2}{|c|}{$\begin{array}{l}\text { Collinearity } \\
\text { Statistics }\end{array}$} \\
\hline Model & & B & $\begin{array}{l}\text { Std. } \\
\text { Error }\end{array}$ & Beta & & & $\begin{array}{c}\text { Tolera } \\
\text { nce }\end{array}$ & VIF \\
\hline \multirow[t]{3}{*}{1} & (Constant) & 20,693 & 7,842 & & $\begin{array}{r}2,63 \\
9\end{array}$ & 011 & & \\
\hline & Self efficacy & 327 & 153 & 313 & $\begin{array}{r}2,13 \\
7\end{array}$ & ,037 & ,440 & 2,273 \\
\hline & $\begin{array}{l}\text { Adversity } \\
\text { quotient }\end{array}$ & ,443 & , 147 & ,441 & $\begin{array}{r}3,01 \\
4\end{array}$ & ,004 & ,440 & 2,273 \\
\hline
\end{tabular}

a. Dependent Variable: Entrepreneurial intention

Based on the Table 1, the regression equation model can be obtained as follows:

$$
Y=a+b_{1} X_{1}+b_{2} X_{2} \rightarrow Y=20,693+0,327 X_{1}+0,443 X_{2}
$$

$\mathrm{Y}=$ Entrepreneurial intention

$\mathrm{a}=$ Constants from the regression equation

$b_{1}, b_{2}=$ regression coefficient value

$\mathrm{X}_{1}=$ independent variable (Self efficacy) 
$\mathrm{X}_{2}=$ independent variable (Adversity quotient)

The explanation of the equations are:

a. The constant value (a) is 20,693, it means that if there are no variables of self efficacy and adversity quotient, the entrepreneurial intention of students of Grade XI of State Vocational School 1 Kanor Marketing Department will increase by 20,693 .

b. The regression coefficient $\mathrm{X}_{1}$ has a positive influence of 0,327 , it means that each increasing in self efficacy variable will increase the entrepreneurial intention of students of Grade XI of State Vocational School 1 Kanor Marketing Department in the amount of 0,327.

c. The regression coefficient $\mathrm{X}_{2}$ has a positive influence of 0.443 , it means that each increasing in the adversity quotient variable will increase the entrepreneurial intention of students of Grade XI of State Vocational School 1 Kanor Marketing Department of 0,443

Table 2. Results of the Determination Coefficient $\left(R^{2}\right)$ Model Summary

\begin{tabular}{llrcrrr}
\hline Model & $\mathrm{R}$ & R Square & $\begin{array}{c}\text { Adjusted R } \\
\text { Square }\end{array}$ & $\begin{array}{c}\text { Std. Error of the } \\
\text { Estimate }\end{array}$ & Durbin-Watson \\
\hline 1 &, $707^{\mathrm{a}}$ &, 500 &, 481 & 4,392 & 1,955 \\
\hline
\end{tabular}

a. Predictors: (Constant), Adversity quotient, Self efficacy

b. Dependent Variable: Entrepreneurial intention

The results of this test get a coefficient of determination $\left(R^{2}\right)$ from Adjusted R Square of 0,481 , it means that $48 \%$ of entrepreneurial intentions of Grade XI students of SMK Negeri 1 Kanor Marketing Department are influenced by self efficacy and adversity quotient variables, while the remaining $52 \%$ are explained by other factors that out of this research variables.

Significant Test of Partial Effect ( $t$ test) to determine the effect of individual independent variables on the dependent variable can be explained as follows:

Table 3 Significant Test Results for Persial Influence ( $t$ test ) Coefficients $^{\mathbf{a}}$

\begin{tabular}{|c|c|c|c|c|c|c|}
\hline \multirow{2}{*}{\multicolumn{2}{|c|}{ Model }} & \multicolumn{2}{|c|}{ Unstandardized Coefficients } & $\begin{array}{c}\text { Standardized } \\
\text { Coefficients }\end{array}$ & \multirow[b]{2}{*}{$\mathrm{t}$} & \multirow[b]{2}{*}{ Sig. } \\
\hline & & B & Std. Error & Beta & & \\
\hline \multirow[t]{3}{*}{1} & (Constant) & 20,693 & 7,842 & & 2,639 & 011 \\
\hline & Self efficacy & 327 & 153 & 313 & 2,137 & ,037 \\
\hline & Adversity quotient & 443 & 147 & ,441 & 3,014 & ,004 \\
\hline
\end{tabular}

a. Dependent Variable: Entrepreneurial intention

Source: data processed by researchers (2018)

a. The partial effect of self efficacy variables (X1) on entrepreneurial intentions (Y) in Grade XI students of State Vocational School 1 Kanor, Marketing Department. 
The results of linear regression analysis self efficacy variables get a significant value of 0,037 . The significant value is smaller than the significant level of 0,05 . It can be concluded that the $\mathrm{H} 1$ hypothesis is accepted. Thus the self efficacy variable is partially proven to have a significant effect on entrepreneurial intentions in Grade XI students of State Vocational School 1 Kanor, Marketing Department.

b. The partial influence of the adversity quotient variable (X2) on entrepreneurial intentions (Y) in Grade XI students of State Vocational High School 1 Kanor, Marketing Department.

The results of linear regression analysis for the adversity quotient variable get a significant value of 0,004 . The significant value is smaller than the significant level of 0,05 . It can be concluded that the $\mathrm{H} 2$ hypothesis is accepted. Thus the self efficacy variable is partially proven to have a significant effect on entrepreneurial intentions in XI Grade students of State Vocational School 1 Kanor, Marketing Department.

c. Significant Test Results of Simultaneous Influence (f test)

The $f$ test is used to determine the effect of simultaneous independent variables on the dependent variable between the self efficacy variable (X1) and the adversity quotient variable (X2) on entrepreneurial intention variables (Y) can be explained as follows:

Table 4 Significant Test Results of Simultaneous Influence (f test) ANOVA $^{a}$

\begin{tabular}{|c|c|c|c|c|c|}
\hline \multirow{2}{*}{$\begin{array}{l}\text { Model } \\
1\end{array}$} & & Sum of Squares & df & Mean Square & $\mathrm{F}$ \\
\hline & \multirow[t]{2}{*}{ Regression } & & & & \multirow{3}{*}{26,469} \\
\hline & & 1021,108 & 2 & 510,554 & \\
\hline & Residual & 1022,320 & 53 & 19,289 & \\
\hline & Total & 2043,429 & 55 & & \\
\hline
\end{tabular}

a. Dependent Variable: Entrepreneurial intention

b. Predictors: (Constant), Adversity quotient, Self efficacy

The analysis results in $\mathrm{F}$ column obtained $\mathrm{F}_{\text {count }}$ value of 26,469 and obtained a significant value of 0,000 smaller than the significance level of 0,05 and it is concluded that the H3 hypothesis is accepted. It means that the self efficacy variable and adversity quotient variables simultaneously have a significant effect on the entrepreneurial intention variable in Grade XI students of State Vocational School 1 Kanor, Marketing Department.

\section{Discussion}

Based on the results of the research described, the discussion of this research is as follows: 


\section{Partial Effect of Self Efficacy on Entrepreneurial Issues}

Based on the results of the t-test analysis that the self efficacy variable obtained a significant value of 0.037 below 0.05 , then the hypothesis could be accepted. Thus it is evident that there is a partial effect of self efficacy on entrepreneurial intentions in Grade XI students of SMK Negeri 1 Kanor Department of Marketing. The higher the self efficacy, the higher the intention of entrepreneurship in students of Grade XI of SMK Negeri 1 Kanor, Marketing Department. Conversely the lower self efficacy, then the lower the intention of entrepreneurship students. In accordance with the self efficacy indicators students have confidence in their ability to entrepreneurship, students can achieve the desire in entrepreneurship, students have confidence in themselves to have a business, students can learn from the experience of others to be able to choose a career as an entrepreneur and students have a great strength for entrepreneurship. Students already have good self-efficacy when it is associated with entrepreneurial intentions, so that the students are confident in their abilities to overcome the problems when they want to become entrepreneurs.

Adnyana \& Purnami (2016) explained that the positive effect of self efficacy on entrepreneurial intentions, the higher the self efficacy, the higher the intention of entrepreneurship when a person's high confidence in their ability be able to try, the greater the desire to become an entrepreneur. The high self-efficacy of students, the higher the intention of entrepreneurship (Anggraeni \& Nurcaya, 2016). The process of selecting and adapting to entrepreneurial career choices in his life can be described through the level of self efficacy. This study has a causal relationship from previous research, that is continuing the final conclusion that self efficacy influences entrepreneurial intentions (Flavius, 2010).

The results of this study in accordance with the results of research conducted by Wijayanto (2014) concluded that partial self-efficacy had a significant effect on the intention of entrepreneurship in students of the Management Study Program at the Faculty of Economics, Tarumanegara University. Other studies also concluded that self efficacy influences entrepreneurial intentions in Economics Education Study Program students (Rapii \& Juani, 2015).

Students who have very strong self-confidence will be confident in their abilities and encourage the desire to become entrepreneurs and be able to act as desired. Conversely, if students have low self-confidence, they will doubt with their abilities and do not have the urge to become entrepreneurs. In accordance with the research conducted by Puspitaningtyas (2017), it was concluded that the high self-efficacy of students would encourage the desire for entrepreneurship primarily driven by high self-confidence and would strengthen the individual's confidence to be able to behave and act as desired. Each student has a different level of self efficacy that will affect to the level of confidence in the ability to do something, achieve goals, learn from experience, and the strength of student entrepreneurship. 


\section{Effect of Partial Adversity Quotient on Entrepreneurial Intention}

Based on the results of the t-test analysis that the adversity quotient variable obtained a significant value of 0.004 below 0.05 , the hypothesis could be accepted. Thus it is evident that there is a partial influence of adversity quotient on entrepreneurial intentions in Grade XI SMK Negeri 1 Kanor, Marketing Department. The higher the adversity quotient, the higher the intention of entrepreneurship in the Grade XI students of SMK Negeri 1 Kanor Marketing Department. Conversely the lower the adversity quotient, the lower the entrepreneurial intention of students. Adversity quotient is the most dominant variable influencing entrepreneurial intentions of Grade XI students of SMK Negeri 1 Kanor Marketing Department. Students who already have good adversity quotient when associated with entrepreneurial intentions, the student also has the ability to be able to overcome emotions, overcome fears and failures when he wants to become an entrepreneur. In accordance with the indicator of adversity quotient, students can face difficulties by getting back up, students can face all challenges of entrepreneurship, students can control their emotions in making decisions, students can recognize the risks that occur in entrepreneurship, and students can overcome problems in entrepreneurship.

The higher the level of adversity quotient, the more increasing the intention of student entrepreneurship, and on the contrary the lower the adversity quotient, the lower the intention of student entrepreneurship (Zahreni, Sari, \& Pane, 2006). Individuals who have intelligence in facing obstacles are able to capture business opportunities because of their ability to turn barriers into opportunities (Srimulyani, 2013). Adversity quotient is closely related in carrying out the entrepreneurial process because running a personal business requires courage to face failure and has the willingness to try continuously until it is successful.

The results of this study in accordance with the results of a study conducted by Julita \& Prabowo (2018) concluded that adversity quotient had a positive and significant effect on entrepreneurial intentions in the Management Study Program of Soegijapranata Catholic University Semarang, the higher the adversity quotient the stronger the intention of entrepreneurship.

High adversity quotient in students will increase their enthusiasm in entrepreneurship, where students will have the ability to get business opportunities because students have the ability to face difficulties, can face challenges, can control themselves, can recognize risks, have the ability to overcome problems and can turning a difficulty into a big opportunity. By having a high adversity quotient, it will be easy to pursue a profession as an entrepreneur. This is in line with research (Mayasari \& Dyah, 2017) concluded that in order to improve adversity intelligence it is necessary to increase the ability to capture business opportunities because they have the ability to bear risk, creativity, resource mobilization, and independence. 


\section{The Influence of Self Efficacy and Adversity Quotient Simultaneously on Entrepreneurial Intention}

Self efficacy and adversity quotient are important factors in influencing entrepreneurial intentions of Grade XI students of SMK Negeri 1 Kanor, Marketing Department. Based on the results of the f test analysis, the value of $F_{\text {count }}$ is 26,469 with a significant value of 0,000 smaller than the value of the significant level of 0,05 so that it can be concluded that the variables of self efficacy and adversity quotient variables simultaneously have a positive and significant effect on the entrepreneurial intention variable in Grade XI students of SMK Negeri 1 Kanor, Department of Marketing. The higher the self efficacy and adversity quotient, the higher the intention of entrepreneurship in the Grade XI students of SMK Negeri 1 Kanor, Marketing Department. Conversely the lower the self efficacy and adversity quotient, the lower the intention of student entrepreneurship.

The results of this study in accordance with the results of research conducted by Fradani (2016) concluded that self-efficacy and adversity intelligence simultaneously affect entrepreneurial intentions of students of SMK Negeri 2 Nganjuk, which means that the higher self-efficacy and adversity intelligence the higher the intention of entrepreneurship.

The results of the correlation coefficient value of self efficacy variable with entrepreneurial intention get a value of 0.327 while the correlation coefficient of the adversity quotient variable with entrepreneurial intention gets a value of 0,443 . It means that the adversity quotient variable has a greater influence on entrepreneurial intention because it obtains the bigger correlation coefficient.

The ability of self efficacy and adversity quotient variables to explain its influence on entrepreneurial intentions is shown by the coefficient of determination $\left(R^{2}\right)$ from Adjusted R Square of 0.481 which means 48 percent. It can be concluded that the ability of self efficacy and adversity quotient variables explain the effect on entrepreneurial intentions of Grade XI students State Vocational School 1 Kanor Marketing Department by 48 percent. This information explains that there are still other factors or other varables of 51.9\% in addition to self efficacy and adversity quotient that can affect the entrepreneurial intention of students of SMK Negeri 1 Kanor.

\section{CONCLUSION}

Based on the results of research and discussion, the conclusions of this study are as follows: 1) there is an effect of self efficacy on entrepreneurial intentions in Grade XI Marketing Department of SMK Negeri 1 Kanor Bojonegoro, 2) there is an adversity quotient influence on entrepreneurial intentions in Grade XI SMK Negeri 1 Kanor Bojonegoro, Marketing Department, 3) there are simultaneous effects of self efficacy and adversity quotient on entrepreneurial intentions in Grade XI Marketing Department of SMK Negeri 1 Kanor Bojonegoro. Based on the conclusions, the suggestion is given that students should do practice constantly and join in entrepreneurship learning, entrepreneurship practices, and exhibitions, 
hence student's self efficacy and adversity quotient can increase, follow the businesses development around them and participate in entrepreneurial activities held at school and outside school to gain a lot of experience in entrepreneurship. Later students will have strong confidence in their abilities and better understand the challenges, obstacles, risks and everything that will be happen in the future, therefore students will ready to become entrepreneurs.

\section{REFERENCES}

Adnyana, I. G. L. A., \& Purnami, N. M. 2016. Effect of Entrepreneurship Education, Self Efficacy and Locus of Control on Entrepreneurial Intention. E-Jurnal Manajemen Unud, 5(2), 1160-1188

Anggraeni, D. A. L., \& Nurcaya, I. N. 2016. The Role of Self-Efficacy in Mediating the Effects of Entrepreneurship Education on the Intention of Entrepreneurship. E-Jurnal Manajemen Unud, 5(4), 2424-2453

Evaliana, Y. 2015. The Effect of Self-Efficacy and Family Environment on Student Entrepreneurship Interests. Jurnal Pendidikan Bisnis Dan Manajemen, 1(1), 61-70

Flavius, T. E. 2010 . Gender, Entrepreneurial Self-Efficacy, And Entrepreneurial Attitude Orientations: The Case of The Caribbean. International Business \& Economics Research Journal, 9(13), 17-32. https://doi.org/10.19030/iber.v9i13.650

Fradani, A. C., 2016 . Effect of Family Support, Adversity Intelligence and SelfEfficacy on Student Entrepreneurial Intention SMK Negeri 2 Bojonegoro. Jurnal Edutama, 3(1), 46-62

Lechner, C.M., Sortheix, F.M., Obschonka, M., Salmela-Aro, K., 2018. What drives future business leaders? How work values and gender shape young adults' entrepreneurial and leadership aspirations. Journal of Vocational Behavior 107, 57-70. https://doi.org/10.1016/j.jvb.2018.03.004

Mayasari, V., \& Dyah, P. 2017. Analysis of the Effect of Adversity Intelligence, Entrepreneurship and Internal Locus of Control Personality on Entrepreneurial Intensity (Study at FEB Jenderal Soedirman University). Jurnal Ilmiah Pendidikan Ekonomi, 2(1), 1-6 (Indonesian origin)

Ng, T. 2013. Organizational Resilience and Adversity Quotient Of Singapore Company. Journal Businness, 65(17).

Ozgul, U., \& Kunday, O., 2015. Conceptual Development of Academic Entrepreneurial Intentions Scale. Procedia - Social and Behavioral Sciences, World Conference on Technology, Innovation and Entrepreneurship 195, 881-887. https://doi.org/10.1016/j.sbspro.2015.06.367

Setiawan, J.L. 2014. Examining Entrepreneurial Self-efficacy among Students. Procedia - Social and Behavioral Sciences, The 5th Indonesia International Conference on Innovation, Entrepreneurship, and Small 
Business (IICIES 2013) 115, 235-242. https://doi.org/10.1016/j.sbspro.2014.02.431

Puspitaningtyas, Z., 2017. The Effect of Self-Efficacy and Knowledge of Business Financial Management on Entrepreneurial Intention. Jurnal Wira Ekonomi Mikroskil, 7(2), 141-150 (Indonesian origin)

Rapii, M., \& Juani, M. 2015. Analysis of the Effect of Locus of Control, Self Efficacy and Need for Achievement on Entrepreneurial Intention in Economics Education Study Program Students. Jurnal Education, 10(1), 1-15 (Indonesian origin)

Wijaya, T. 2007. Relationship between adversity intelligence and entrepreneurial intentions (empirical studies in students SMKN 7 Yogyakarta). Jurnal Manajemen Dan Kewirausahaan, 9(2), 117-127. https://doi.org/10.1007/978-1-1411-1-1438 (Indonesian origin)

Wijayanto, H. 2014. The Effect of Self-Efficacy and Environment on the Intention of Student Entrepreneurship (Study on Students of the Management Study Program at the Faculty of Economics). Jurnal Manajemen (Vol. XVIII) (Indonesian origin)

Zahreni, S. \& Malini, S. 2014. Relationship between Adversity Quotient and Entrepreneurial Satisfaction in Women Entrepreneurs in Medan City. Jurnal, Medan: Fakultas Psikologi. Universitas Sumatra Utara (Indonesian origin) 